\title{
Kecenderungan Kemandirian Lansia di PSTW J. Soenarti Nasution dan Pondok Lansia Tulus Kasih Kota Bandung
}

\author{
Lia Meilianingsih $^{1}$, Ghina Roshalina ${ }^{2}$, Ridwan Setiawan $^{3}$
}

\begin{abstract}
Abstrak
Penelitian ini dilatarbelakangi adanya peningkatan jumlah penduduk tua.Berdasarkan sensus penduduk tahun 2017, Jawa Barat termasuk 8 besar jumlah lansia terbanyak. Semakin lanjut usia, mereka akan mengalami kemunduran terutama di bidang kemampuan fisik. Hal ini mengakibatkan pula timbulnya gangguan sehingga dapat meningkatkan ketergantungan yang memerlukan bantuan orang lain. Penelitian ini bertujuan untuk mengetahui kecenderungan kemandirian lansia. Jenis penelitian yang digunakan adalah deskriptif, populasi 51 lansia, sampel 34 lansia, teknik pengambilan sampel menggunakannonprobability sampling jenis purposive sampling, instrumen penelitian menggunakan Barthel Indeks, Berg Balance Scale dan Pedoman Kuesioner. Analisa data menggunakan analisa univariat dilanjutkan dengan analisa Run Test. Lebih dari setengahnya responden ketergantungan sebagian dalam kemandirian.Hampir setengahnya responden ketergantungan sebagian yang berusia $\geq 70$ tahun.Lebih dari setengahnya responden memiliki gangguan pergerakan terkait imobilitas. Hampir setengahnya responden memiliki resiko jatuh tinggi terkait mudah jatuh. Hasil analisa run test menunjukkan bahwa ketiga faktor yang melatarbelakangi kemandirian lansia memiliki nilai $\mathrm{p}>0,05$ yang berarti kecenderungan kemandirian lansia diakibatkan oleh faktor usia, imobilitas dan mudah jatuh. Faktor imobilitas memiliki p value paling tinggi yaitu 0,794 maka dapat disimpulkan faktor yang cenderung melatarbelakangi kemandirian lansia paling banyak adalah faktor imobilitas.Disarankan kepada pengelola panti untuk dipertahankan program yang sudah rutin diadakan sehingga tetap menjaga kondisi lansia seperti latihan penguatan otot, latihan fleksibilitas dan keseimbangan.
\end{abstract}

Kata kunci : Kecenderungan kemandirian, lansia

\begin{abstract}
This research is motivated by the increasing of old population. Based on the population census in 2017, West Java including 8 large number of elderly people. Increasingly older, they will experience setbacks especially in the field of physical ability. This resulted in the occurrence of interference so as to increase dependence that requires the help of others. This study aims to determine the tendency of independence of the elderly. The research type used is descriptive, population 51 elderly, sample 34 elderly, sampling technique using nonprobability sampling type purposive sampling, research instrument using Barthel Index, Berg Balance Scale and Questionnaire Guide. Data analysis using univariate analysis followed by Run Test analysis. More than half of the dependents are partly dependent on selfreliance. Almost half of the dependents are $\geq 70$ years old. More than half of the respondents had impaired immobility-related movements. Almost half of the respondents have a high fall risk associated with falling easily. The result of run test analysis showed that the three factors behind the independence of the elderly have a value of $p>0.05$ which means the tendency of elderly independence caused by age factor, immobility and easy to fall. The immobility factor has the highest $p$ value of 0.794 then it can be concluded that the factor that tends to be the background of the independence of the elderly is the most immobility factor. It is suggested to the orphanage organizer to maintain the program that has been routinely held so as to maintain the elderly conditions such as muscle strengthening exercises, flexibility and balance exercises.
\end{abstract}

Keywords: Trend of independence, elderly 


\section{PENDAHULUAN}

Tahap dewasa merupakan tahap tubuh mencapai titik perkembangan yang maksimal.Setelah itu, tubuh mulai menyusut dikarenakan berkurangnya jumlah sel-sel yang ada di dalam tubuh. Sebagai akibatnya, tubuh juga akan mengalami penurunan fungsi secara perlahan-lahan, itulah yang dikatakan proses penuaan (Maryam dkk, 2008). Proses menua merupakan proses sepanjang hidup, tidak hanya dimulai pada satu waktu tertentu, tetapi dimulai sejak permulaan kehidupan. Menua bukan suatu penyakit, tetapi merupakan proses yang berangsurangsur mengakibatkan perubahan yang kumulatif, yaitu merupakan proses penurunan daya tahan tubuh dalam menghadapi rangsangan dari dalam dan luar tubuh yang berakhir dengan kematian (Dewi, 2014). Lanjut usia atau yang lazim disingkat dengan Lansia adalah warga Indonesia yang berusia $\geq 60$ tahun (Badan Pusat Statistik, 2015).

Negara Indonesia sudah mulai masuk ke kelompok negara berstruktur tua (ageing population). Struktur ageing population merupakan cerminan dari semakin tingginya rata-rata Usia Harapan Hidup (UHH) penduduk Indonesia. Tingginya UHH merupakan salah satu indikator keberhasilan pencapaian pembangunan nasional terutama di bidang kesehatan. Sejak tahun 2004-2015 memperlihatkan adanya peningkatan UHH di Indonesia dari 68,6 tahun menjadi 70,8 tahun dan proyeksi tahun 2030-2035 mencapai 72,2 tahun (Badan Pusat Statistik, 2015). Berdasarkan data proyeksi penduduk, diperkirakan tahun 2017 terdapat 23,66 juta jiwa penduduk lansia di Indonesia $(9,03 \%)$. Suatu negara dikatakan berstruktur tua jika mempunyai populasi lansia di atas 7\% (Soewono dalam Analisis Lansia di Indonesia). Hasil sensus penduduk pada tahun 2017, Jawa Barat termasuk ke dalam 10 besar yaitu pada urutan ke 8 jumlah lansia terbanyak yakni 8,34\% (Pusat Data dan Informasi).

Perubahan struktur penduduk mempengaruhi beban ketergantungan. Salah satunya adalah angka beban ketergantungan penduduk tua. Akibat penurunan angka kelahiran dan makin tingginya angka harapan hidup penduduk Indonesia, jumlah penduduk yang berusia tua pun menjadi relatif besar, yang berarti angka ketergantungan penduduk tua juga telah meningkat. Rasio ketergantungan penduduk tua (old dependency ratio) adalah angka yang menunjukkan tingkat ketergantungan penduduk tua pada penduduk usia produktif. Angka tersebut merupakan perbandingan antara jumlah penduduk tua (60 tahun ke atas) dengan jumlah penduduk produktif (15-59 tahun). Dari angka ini tercermin besarnya beban ekonomi yang harus ditanggung penduduk produktif untuk membiayai penduduk tua. 
Kemandirian lansia merupakan perilaku yang dilihat dari perlakuan lanjut usia terhadap diri sendiri dan lingkungan yang berkaitan dengan kemampuannya melakukan aktivitas kesehatan, aktivitas ekonomi, dan aktivitas sosial. Semakin lanjut usia, mereka akan mengalami kemunduran terutama bidang kemampuan fisik, yang dapat menyebabkan penurunan peran sosial. Hal ini mengakibatkan pula timbulnya gangguan dalam hal mencukupi kebutuhan hidup sehingga meningkatkan ketergantungan yang memerlukan bantuan orang lain.Ketergantungan lanjut usia disebabkan kondisi orang lanjut usia banyak mengalami kemunduran fisik, kemampuan kognitif, serta psikologis, artinya lansia mengalami perkembangan dalam bentuk perubahan yang mengarah pada perubahan yang negatif. Akibatnya perubahan fisik lansia akan mengalami gangguan mobilitas fisik yang akan membatasi kemandirian lansia dalam memenuhi aktifitas sehari-hari (Nugroho, 2002).

Aktivitas kehidupan harian yang dalam istilah bahasa inggris disingkat ADL (Activity of Daily Living) adalah merupakan aktivitas pokok bagi perawatan diri. ADL yang terdiri dari 13 aktivitas kemandirian yaitu makan, minum, berpindah dari kursi ke tempat tidur/ sebaliknya, personal toilet, keluar/masuk toilet, mandi, jalan di permukaan datar, naik turun tangga, mengenakan pakaian, control bowel (BAB), kontrok bladder (BAK), olahraga/latihan dan rekreasi/ pemanfaatan waktu luang. Pengkajian ADL penting untung mengetahui tingkat ketergantungan. Dengan kata lain, besarnya bantuan yang diperlukan dalam aktivitas kehidupan sehari-hari serta untuk menyusun rencana perawatan jangka panjang (Tamher \& Noorkasiani, 2009).

Kemampuan pada lansia harus diidentifikasi, yaitu apakah lansia masih dapat beraktivitas dengan mandiri dan seberapa besar kemampuan yang masih dimiliki.Kemampuan fungsional ini harus dipertahankan semandiri mungkin dan harus diperhatikan dalam melakukan kegiatan sehari-hari, sehingga perlu dilakukan pengkajian kemampuan fungsional untuk melihat kemampuan lansia dalam melakukan perawatan diri mereka sendiri yang dimulai dari aktivitas kehidupan harian.

Faktor yang mempengaruhi tingkat kemandirian lansia dalam melakukan aktivitas kehidupan sehari-hari, seperti: usia, imobilitas, dan mudah jatuh (Nugroho, 2008). Pengkajian kemampuan fungsional sangat penting, terutama ketika terjadi hambatan pada kemampuan lansia dalam melaksanakan fungsi kehidupan sehari-harinya. Pengkajian kemampuan fungsional merupakan pengukuran kemampuan seseorang dalam melakukan aktivitas kehidupan sehari-hari secara mandiri. Penentuan kemandirian 
fungsional

dilakukan

untuk

mengidentifikasi kemampuan dan

keterbatasan klien, serta menciptakan pemilihan intervensi yang tepat

(Kushariadi, 2012).

Menurut Ratna Wulandari (2016)

Tingkat Kemandirian Lansia Dalam Pemenuhan Kebutuhan ADL di UPT PSLU Blitar di Tulungagung, sampel yang digunakan yaitu lansia yang berumur $>60$ tahun ke atas sebanyak 44 lansia, faktor pertama yang mempengaruhi kemandirian lansia yaitu kelenturan, lansia yang mengalami masalah kelenturan sebanyak 8 lansia $(18,2 \%)$ dan yang tidak mengalami masalah kelenturan sebanyak 36 lansia (36 lansia). Faktor kedua yaitu keseimbangan, lansia yang mengalami masalah keseimbangan sebanyak 13 lansia $(29,5 \%)$ dan yang tidak mengalami masalah keseimbangan sebanyak 31 lansia $(70,5 \%)$. Faktor ketiga yaitu self efficacy (keberdayagunaan mandiri) yaitu lansia yang punya keberanian dalam melakukan aktivitas/olahraga, didapatkan hasil 41 lansia $(93,2 \%)$ memiliki self efficacy dan 3 lansia $(6,8 \%)$ tidak memiliki self efficacy.Adapun yang mengalami masalah kelenturan, keseimbangan dan self efficacy disebabkan karena lansia yang jarang melakukan aktivitas dan cenderung kurang aktif sehingga menimbulkan kekuatan otot.

Menurut Rohaedi, S, Putri, S.T dan Karimah, AD (2016) mengenai Tingkat Kemandirian Lansia dalam Activities
Daily Living di PSTW Senja Rawi Kota Bandung dengan responden lansia berusia 60-69 tahun yang berjumlah 21 lansia. Dalam data yang ditemukan pada saat penelitian, didapatkan bahwa 3 lansia (14\%) mengalami ketergantungan total, 15 lansia (72\%) mengalami ketergantungan sebagian dan 3 lansia (14\%) mandiri. Adapun yang mengalami ketergantungan total dan sebagian disebabkan oleh penyakit stroke dan parkinson.

Menurut Lalu tanjung Wiraguna (2014) mengenai Gambaran Tingkat Kemandirian Lansia dalam Activities Daily Living (ADL) pada lansia di Desa Leyangan Kecamatan Ungaran Timur Kabupaten Semarang dengan populasi lansia yang berumur 60-75 tahun yaitu sebanyak 79 responden, didapatkan hasil bahwa responden yang mandiri sebanyak 69 orang $(87,3 \%)$ dan yang tidak mandiri sebanyak 10 orang $(12,7 \%)$. Dilihat dari hasil di atas sebagian besar reponden yang mandiri dikarenakan masih memiliki fungsi fisiologis yang baik dan umurnya dibawah 70 tahun. Responden yang tidak mandiri dikarenakan gangguan fungsi fisiologi pada bagian tubuh lansia, usia di atas 70 tahun dan dalam keadaan sakit.

\section{METODE PENELITIAN}

Desain penelitian yang digunakan adalah deskriptif, yaitu untuk mengetahui gambaran distribusi frekuensi responden berdasarkan masing-masing variabel yang 
diteliti.Dalam penelitian ini, populasi yang diambil adalah lansia yang tinggal di PSTW J. Soenarti Nasution dan Pondok Lansia Tulus Kasih Kota Bandung sebanyak 51 orang.Sampel dalam penelitian ini sebanyak 34 orang dan harus memenuhi kriteria inklusi.

Kriteria inklusi adalah karakteristik yang dapat dimasukkan atau layak untuk diteliti, yaitu lansia yang mampu berkomunikasi dengan baik secara verbal dan bersedia menjadi responden. Instrumen penelitian dalam penelitian ini adalah Barthel Indeks, Berg Balance Scale dan Pedoman Kuesioner. Teknik pengambilan sampel menggunakan Nonprobability Sampling jenis Purposive Sampling. Analisa data menggunakan analisa univariat dilanjutkan dengan analisa Run Test untuk mengetahui kecenderungan kemandirian lansia.

\section{HASIL DAN PEMBAHASAN}

\section{Hasil Penelitian}

Tabel 1. Kemandirian Lansia di PSTW J. Soenarti Nasution dan Pondok Lansia Tulus Kasih Kota Bandung 2018

\begin{tabular}{lcc}
\hline \multicolumn{1}{c}{ Kriteria } & $\begin{array}{c}\text { Frekuensi } \\
\text { (Jumlah) }\end{array}$ & $\begin{array}{c}\text { Persentase } \\
(\boldsymbol{\%})\end{array}$ \\
\hline Mandiri & 15 & $44.1 \%$ \\
Sebagian & 18 & $52.9 \%$ \\
Total & 1 & $2.9 \%$ \\
\hline \multicolumn{1}{c}{ Total } & $\mathbf{3 4}$ & $\mathbf{1 0 0 . 0} \%$ \\
\hline
\end{tabular}

Berdasarkan tabel 1 dapat di deskripsikan bahwa hampir dari setengahnya responden mandiri dengan jumlah responden 15 orang $(44,1 \%)$, lebih dari setengahnya responden ketergantungan sebagian dengan jumlah responden 18 orang $(52,9 \%)$, dan sebagian kecil dari responden ketergantungan total dengan jumlah responden 1 orang $(2,9 \%)$.

Tabel 2. Kemandirian Lansia terkait Faktor Usia di PSTW J. Soenarti Nasution dan Pondok Lansia Tulus Kasih Kota Bandung 2018

\begin{tabular}{|c|c|c|c|c|c|c|}
\hline \multirow{3}{*}{ Kemandirian } & \multicolumn{4}{|c|}{ Usia } & \multirow{2}{*}{\multicolumn{2}{|c|}{ Jumlah }} \\
\hline & \multicolumn{2}{|c|}{$\begin{array}{l}<70 \\
\text { tahun }\end{array}$} & \multicolumn{2}{|c|}{$\geq 70$ tahun } & & \\
\hline & (f) & $(\%)$ & (f) & $(\%)$ & (f) & $(\%)$ \\
\hline Mandiri & 3 & 8,8 & 12 & 35,3 & 15 & 44,1 \\
\hline Sebagian & 5 & 14,7 & 13 & 38,3 & 18 & 53 \\
\hline Total & 0 & 0 & 1 & 2,9 & 1 & 2,9 \\
\hline Total & 8 & 23,5 & 26 & 76,5 & 34 & 100 \\
\hline
\end{tabular}

Berdasarkan tabel 2 dapat dilihat bahwa dari 15 lansia yang mandiri terdapat 12 lansia atau hampir setengahnya dari responden $(35,3 \%)$ berusia $\geq 70$ tahun, dari 18 lansia yang ketergantungan sebagian terdapat 13 lansia atau hampir setengahnya dari responden $(38,3 \%)$ berusia $\geq 70$ tahun, sedang dari 1 lansia yang ketergantungan total atau sebagian kecil dari responden $(2,9 \%)$ berusia $\geq 70$ tahun.

Tabel 3. Kemandirian Lansia terkait Faktor Imobilitas di PSTW J. Soenarti Nasution dan Pondok Lansia Tulus Kasih Kota Bandung 2018

\begin{tabular}{ccccccc}
\hline & \multicolumn{9}{c}{ Usia } & \multirow{2}{*}{ Jumlah } \\
\cline { 2 - 6 } Kemandirian & $\begin{array}{c}\text { Tidak } \\
\text { Imobilitas }\end{array}$ & \multicolumn{2}{c}{ Imobilitas } & & \\
\cline { 2 - 6 } & (f) & $(\%)$ & (f) & $(\%)$ & $(\mathrm{f})$ & $(\%)$ \\
\hline Mandiri & 10 & 29,5 & 8 & 23,5 & 18 & 53 \\
Sebagian & 0 & 0 & 15 & 44,1 & 15 & 44,1 \\
Total & 0 & 0 & 1 & 2,9 & 1 & 2,9 \\
\hline Total & 10 & 29,5 & 24 & 70,5 & 34 & 100 \\
\hline
\end{tabular}

Berdasarkan tabel 3 dapat dilihat bahwa dari 18 lansia yang mandiri terdapat 10 lansia atau hampir setengahnya dari responden $(29,5 \%)$ termasuk kategori tidak 
imobilitas, dari 15 lansia yang ketergantungan sebagian terdapat 15 lansia atau hampir setengahnya dari responden $(44,1 \%)$ termasuk dalam kategori imobilitas, sedangkan dari 1 lansia yang ketergantungan total atau sebagian kecil $(2,9 \%)$ termasuk dalam kategori imobilitas.

Tabel 4. Kemandirian Lansia terkait Faktor Mudah Jatuh di PSTW J. Soenarti Nasution dan Pondok Lansia Tulus Kasih Kota Bandung 2018

\begin{tabular}{ccccccc}
\hline & \multicolumn{4}{c}{ Usia } & & \\
\cline { 2 - 7 } Kemandiria & \multicolumn{2}{c}{$\begin{array}{c}\text { Resiko } \\
\text { Jatuh }\end{array}$} & \multicolumn{2}{c}{$\begin{array}{c}\text { Resiko } \\
\text { Jatuh }\end{array}$} & \multirow{2}{*}{ Jumlah } \\
& $\begin{array}{c}\text { Rendah } \\
\text { Tinggi }\end{array}$ & \multicolumn{2}{c}{ Ting } & \\
\cline { 2 - 7 } & (f) & $(\%)$ & (f) & $(\%)$ & (f) & $(\%)$ \\
\hline Mandiri & 12 & 35,3 & 6 & 17,7 & 18 & 53 \\
Sebagian & 1 & 2,9 & 14 & 41,2 & 15 & 44,1 \\
Total & 0 & 0 & 1 & 2,9 & 1 & 2,9 \\
\hline Total & 13 & 44,1 & 19 & 55,9 & 34 & 100 \\
\hline
\end{tabular}

Berdasarkan tabel 4 dapat dilihat bahwa dari 18 lansia yang mandiri terdapat 12 lansia atau hampir setengahnya dari responden $(35,3 \%)$ termasuk kategori resiko jatuh rendah, dari 15 lansia yang ketergantungan sebagian terdapat 14 lansia atau hampir setengahnya dari responden $(41,2 \%)$ termasuk kategori resiko jatuh tinggi, sedangkan dari 1 lansia yang ketergantungan total atau sebagian kecil dari responden $(2,9 \%)$ termasuk kategori resiko jatuh tinggi.

Tabel 5. Kecenderungan Kemandirian Lansia

\begin{tabular}{llll}
\hline & $\begin{array}{l}\text { Faktor } \\
\text { Usia }\end{array}$ & $\begin{array}{l}\text { Faktor } \\
\text { Imobilitas }\end{array}$ & $\begin{array}{l}\text { Faktor } \\
\text { mudah } \\
\text { Jatuh }\end{array}$ \\
\hline $\begin{array}{l}\text { Asymp. } \\
\text { Sig. (2 } \\
\text { tailed) }\end{array}$ & 0,719 & 0,794 & 0,655 \\
\hline
\end{tabular}

Variabel di atas memiliki nilai signifikan p. value $>0,05$. Maka kesimpulan yang dapat ditarik adalah kecenderungan kemandirian lansia berpeluang diakibatkan oleh ketiga faktor tersebut. Nilai p. value paling tinggi adalah faktor imobilitas yaitu 0,794 sehingga kecenderungan kemandirian lansia yang paling berpeluang diakibatkan oleh faktor imobilitas lansia itu sendiri.

\section{Pembahasan}

Hasil analisa pengukuran kecenderungan kemandirian lansia di PSTW J. Soenarti Nasution dan Pondok Lansia Tulus Kasih dengan menggunakan Barthel Indeks menunjukan bahwa lebih dari setengahnya reponden memiliki tingkat ketergantungan sebagian yaitu sebanyak 18 responden $(52,9 \%)$. karena beberapa lansia mengalami gangguan pada imobilitas sehingga memerlukan bantuan dalam beraktivitas.

Penelitian ini didukung penelitian Slamet Rohaedi, dkk (2016) di PSTW Senja Rawi menyatakan mayoritas lansia memiliki ketergantungan sebagian 15 responden $(72 \%)$ dan ketergantungan total sebanyak 3 orang (14\%), karena terdapat beberapa lansia yang menderita penyakit seperti stroke dan parkinson sehingga semua kegiatan dalam memenuhi kebutuhan sehari-harinya perlu bantuan orang lain.

Hasil penelitian menggambarkan, sebagian besar responden yaitu 13lansia 
$(38,3 \%)$ termasuk kategori ketergantungan sebagian merupakan lansia berumur $\geq 70$ tahun keatas, Seiring dengan bertambahnya usia, maka akan semakin menurun kemampuan untuk memenuhi kebutuhan sehari-hari, sehingga ketergantungan pada orang lain semakin meningkat. Hasil penelitian ini mendukung teori yang dikemukakan oleh Maryam (2008) bahwa lansia yang telah memasuki usia 70 tahun, ialah lansia resiko tinggi. Biasanya akan menghalangi penurunan dalam berbagai hal termasuk tingkat kemandirian dalam melakukan aktifitas sehari-hari.

Hasil penelitian menggambarkan, hampir setengahnya dari responden yaitu 15 lansia $(44,1 \%)$ yang termasuk kategori memiliki imobilitas mengalami kemunduruan dalam mobilisasi karena banyaknya keluhan pada kaki seperti nyeri kaki.Sesuai dengan teori (Luckenotte, 1996 dalam Nugroho (2008) imobilitas adalah ketidak mampuan untuk bergerak secara aktif akibat berbagai penyakit atau impairment (gangguan pada alat organ tubuh) yang bersifat fisik atau mental penurunan toleransi aktivitas.

Hasil penelitian menggambarkan, hampir setengahnya dari responden yaitu 14 lansia $(41,2 \%)$ yang termasuk kategori resiko jatuh tinggi. Sesuai dengan pernyataan Ediawati (2013) bila seseorang bertambah tua, kemampuan fisik dan mentalnya perlahan akan menurun. Kemampuan fisik dan mental yang menurun sering menyebabkan jatuh pada lansia, akibatnya akan berdampak pada menurunnya aktivitas kemandirian lansia.

Hasil analisa run test menunjukkan bahwa ketiga faktor yang melatarbelakangi kemandirian lansia memiliki nilai signifikan $\mathrm{p}$. value $>0,05$ sehingga secara keseluruhan kecenderungan kemandirian lansia diakibatkan oleh tiga faktor yaitu faktor usia, faktor imobilitas dan faktor mudah jatuh. Dari ketiga faktor tersebut yang memiliki nilai signifikan paling tinggi yaitu faktor imobilitas sebesar 0,794 sehingga disimpulkan bahwa faktor yang cenderung melatarbelakangi kemandirian lansia paling banyak adalah faktor imobilitas. Sesuai teori yang dikemukakan oleh Nugroho (2008) bahwa lansia banyak mengalami kemunduran fisik, kognitif serta psikologis.Artinya lansia mengalami perkembangan dalam bentuk perubahanperubahan yang mengarah pada perubahan yang negatif. Akibatnya, perubahan fisik lansia akan mengalami gangguan mobilitas fisik yang akan membatasi kemandirian lansia memenuhi aktifitas sehari-hari.

\section{KESIMPULAN DAN SARAN}

Berdasarkan hasil penelitian mengenai kecenderungan kemandirian lansia di PSTW J. Soenarti Nasution dan Pondok Lansia Tulus Kasih Kota Bandung dapat disimpulkan lebih dari setengahnya responden memiliki ketergantungan sebagian dalam pemenuhan ADL.Hampir 
setengahnya dari responden memiliki ketergantungan sebagian pada lansia yang berusia $\geq 70$ tahun terkait faktor usia.Hampir setengahnya dari responden memiliki gangguan pergerakan terkait faktor imobilitas.

Hampir setengahnya dari responden memiliki resiko jatuh tinggi tekait faktor mudah jatuh dan kecenderungan kemandirian lansia berpeluang diakibatkan oleh faktor usia, faktor imobilitas dan faktor mudah jatuh. Nilai signifikan paling tinggi adalah faktor imobilitas, sehingga kecenderungan kemandirian lansia paling berpeluang diakibatkan faktor imobilitas.

\section{1, 2, 3 Poltekkes Kemenkes Bandung}

\section{DAFTAR PUSTAKA}

Badan Pusat Statistik. (2015). Statistik Penduduk lanjut usia (SUSENAS)2015. Badan Pusat Statistik. Jakarta

Dewi, Sofia Rhosma. (2014). Buku Ajar Keperawatan Gerontik. Yogyakarta: DEEPUBLISH

Ediawati, Eka. (2013). Gambaran Tingkat Kemandirian Dalam Actuvity of Daily Living (ADL) Dan Resiko Jatuh Pada Lansia DI Panti Sosial Trsna Wredha Budi Mulia 01 dan 03 Jakarta Timur.(Skripsi, Universitas Indonesia). Diunduh dari : digital_20314351-S43833Gambaran tingkat.pdf
Kushariyadi. (2012). Asuhan Keperawatan Pada Klien Lanjut Usia. Jakarta:Salemba Medika.

Maryam, R. Siti, dkk. (2008). Mengenal Usia Lanjut dan Perawatannya. Jakarta:Salemba Medika.

Nugroho, Wahjudi. (2008). Keperawatan Gerontik \& Geriatrik Edisi 3. Jakarta:EGC.

Pusat Data dan Informasi Kemenkes RI.(2017). INFODATIN Situasi Lanjut Usia.http:file://C:/Users/ acer/Downloads/infodatin-lansia. pdf. Diakses pada tanggal 10 Februari 2018 pukul 19:03

Rohaedi, S., Putri, ST, Karimah, AD.(2016). Tingkat Kemandirian Lansia Dalam Activities Daily Living Di Panti Sosial Tresna Werdha Senja Rawi. Bandung: Fakultas Keperawatan Universitas Pendidikan Indonesia.

Tamher, S. \& Noorkasiani.(2009). Kesehatan Lanjut Usia dengan Pendekatan Askep. Jakarta: Salemba Medika.

Wiraguna, Lalu Tanjung. (2014). Gambaran Tingkat Kemandirian Dalam Activities Daily Living (Adl) Pada Lansia Di Desa Leyangan Kecamatan Ungaran Timur.Semarang: Fakultas Ilmu Keperawatan Sekolah Tinggi Ilmu Kesehatan Ngudi Waluyo

Wulandari, Ratna. (2016). Gambaran Tingkat Kemandirian Lansia Dalam Pemenuhan ADL (Activity Daily Living) di UPT PSLU Blitar di Tulungagung. Blitar: Poltekkes Kemenkes Malang. 